\title{
Will Governmental Incentives in Developing Countries Support Companies to Innovate More? Evidences from Skin Care Patent Applications in Brazil
}

\author{
Ivan Domicio da Silva Souza', Tuanny Leite Almeida², Vania Passarini Takahashi ${ }^{3}$
}

\begin{abstract}
Recent Brazilian Governments have provided incentives to support domestic innovation; however, some claim that the country has set conflicting policies towards innovation, industrial property and biodiversity exploitation. After an analysis of patent applications filled in the Brazilian National Institute of Industrial Property, we observed that current governmental measures have not performed as expected, at least in the skin care industry. Throughout the paper we discuss plausible reasons why this sector has not managed to innovate more, reasons that may affect other businesses as well. This case is exemplary to developing economies that have implemented or are in the process of renewing their innovation policies.
\end{abstract}

Keywords: patents; industrial property; biodiversity; innovation incentives; skin care; brazil.

Faculty of Pharmaceutical Sciences of Ribeirão Preto, University of São Paulo. Av. do Café s/n, postal code: 14.040-903. Ribeirão Preto -SP. Brazil. 'Phone: +55 163602 0256; e-mail: ssdivan@gmail.com; 2Phone: +55 163602 0256; e-mail: tuanny.leite@gmail.com;

3Phone: +55 163602 42883; e-mail: vptakahs@usp.br, 


\section{Introduction}

Bessant and Tidd (2009) consider that one of the most appropriate definitions of innovation is the successful exploitation of new ideas. The authors also state that innovation assumes at least the following four dimensions of change (the 4 Ps of innovation): product innovation (changes in the things an organization offers), process innovation (changes in the ways those things are created or delivered), position innovation (changes in the context in which those things are introduced) and paradigm innovations (changes in the mental models that drive the organization).According to the authors, innovation success apparently depends on two ingredients: resources (personnel, equipment, knowledge, raw material, money etc.) and the capacity to manage them (Bessant and Tidd, 2009).

In terms of resources, the Brazilian territory owns the greatest source of natural assets in the world and has a reasonable deal of Universities and labor force. Besides, the country expended almost $\mathrm{R} \$ 68$ billion with Science and Technology in 201 I, according to the Brazilian Ministry of Science, Technology and Innovation (Brazil, 20I4d). Such amount is four times higher than the investments outlaid ten years earlier, in $200 \mathrm{I}$ (Brazil, 20I4d). Nonetheless, the local Government provided more than $65 \%$ of that capital, either as direct or indirect investments. This fact illustrates the relevance of governmental incentives to encourage innovation development in enterprises; even though, Wonglimpiyarat (2006) reminds us that Governmental programs should be a complementary financing form, instead of the main source of funding.

In terms of innovation management, Brazil is a signatory of international industrial property agreements. Historically, in countries without patent law, innovations concentrated on a narrow set of industries in which secrecy effectively guaranteed exclusivity, so that inventors had enough time to regain their investments (Moser, 2013). On the other hand, in countries with patent law, inventors could use legal protection to establish exclusivity in any industry, so that other factors were more determinative than secrecy effectiveness (Moser, 2013). Indeed, there is a gap in the literature in terms of understanding which factors crucially boost innovation.
Moser (2013), for example, reported that implementing patent law is not necessarily a sufficient condition for higher rates of innovation. Efrat (20I4), in her turn, found that national cultural aspects still influence the ability of resident and non-resident firms to create and maintain innovation in a country. Here, we question if increasing governmental incentives in a developing country would encourage companies to innovate more. In this context, our objective was to verify the results of Brazilian efforts to enhance domestic innovation by means of patent information, from the perspective of technologies related to skin care products.

\section{Background}

This section presents a background regarding the Brazilian policies to enhance innovation. Complementarily, industrial property rights, biodiversity access in Brazil, as well as some particularities of the skin care industry, are also highlighted.

\section{Incentives for innovation in Brazil}

According to Matias-Pereira (201 I), Brazil invests about I\% of its Gross Domestic Product to foster science, research and technology, what is similar to countries such as Spain ( $0.94 \%)$, but far distant from larger economies such as the USA (2.7\%), Japan (3\%) and South Korea (2.5\%). Nonetheless, in the last decade, the Brazilian Government has approved a series of laws and strategic plans aiming to boost internal technological development and innovation.

Brazilian Government formalized its innovation policies by proclaiming two Laws on incentives to research and innovation, that is, Law No. 10,973/2004, which is complemented by Law No. I I, 196/2005 (Brazil, 2004; Brazil, 2005). For example, Law No. II,196/2005 establishes the deduction on income tax of up to $80 \%$ of the expenditures with technological research and technological innovation development, according to the number of researchers hired by the company (Brazil, 2005, Art. 19, § Ist). The same Law determines the deduction on income tax of up to $20 \%$ of the expenditures related to the development of technologies object of granted patents (Brazil, 2005, Art. 19, § 3rd). Indeed, some companies have benefitted from these Laws, for instance, Natura (a Brazilianbased cosmetic company) exceeded US\$ II million grants in tax incentives for innovation in $201 \mathrm{I}$ (Varrichio et al., 2012). Further, data from the latest Technological Innovation Research (PINTEC), organized by the Brazilian Institute of Geography and Statistics from 2006-2008, shows that 22.8\% of the companies in the sample ( 8700 enterprises) resorted to at least one governmental incentive to develop their innovations (Brazil, 20 I0a). 
In compliance with those Laws, the Brazilian Government has launched several financial incentive programs through its public funding agencies, such as the National Bank for Economic and Social Development (BNDES), the National Council for Scientific and Technological Development $(\mathrm{CNPq})$, the Funding for Studies and Projects (FINEP), as well as each Brazilian State Funding Agencies (FAPs). Magalhães et al. (20I I), for example, mention the Research Program in the Characterization, Conservation, Restoration and Sustainable Use of the Biodiversity of São Paulo State (Program BIOTA), an initiative of São Paulo State FAP (FAPESP), which aims at assessing the possibilities of sustainable exploitation of plants and animals with economic potential. Further, in 20 I3, FINEP offered a nonrefundable amount of $\mathrm{R} \$ 16$ million exclusively to cosmetic companies capable of developing innovations in the areas of nanotechnology and biotechnology - the latter, mandatorily with the use of components of the Brazilian biodiversity (Brazil, 2013c). Another example is the program Human Resource Training in Strategic Areas (RHAE) maintained by CNPq, which sponsors scholarships to highly qualified professionals performing research and development activities within enterprises (Brazil, 20I4a).

More recently, in 20 I I, the Brazilian Government announced the plan Brasil Maior (Greater Brazil) that is supposed to intensify national competitiveness through further incentives to technological innovation, research and production, as well as to provide clear advantages for exporters dealing with unfavorable exchange rates (Weiss and Jeffrey, 20I I). A few goals of Brasil Maior are to increase companies' expenditures in research and development, improve the qualification of employees hired in the industries, reinforce innovative micro, small and medium enterprises and diversify Brazilian exports up to the end of 2014 (Brazil, 20I4b).

In spite of the available financial and fiscal incentives, the literature suggests that at least two other complementary factors have impaired innovation development in Brazil. Such factors are patenting policies and access to natural resources, as presented in the following sections.

\section{Industrial property in Brazil}

The Patent Cooperation Treaty (PCT) is an agreement managed by the World Intellectual Property Organization (WIPO) that streamlines patent register in multiple countries. The ranking of applications by means of the PCT is considered a relevant index of technological innovation performance, and Brazil ranks as the sixth among the developing countries, behind of China, South Korea, India, Russia and Singapore. While the USA (the first in the general rank) was responsible for 5I,625 applications, China and Brazil filled 18,617 and 588 applications, respectively, in 2012 (WIPO, 20I3c). Matias-Pereira (20II) declares that the considerable disparity in the number of Brazilian international applications is partially explained by the low proportion of researchers hired to work in local companies. According to the author, in developed countries, $80 \%$ of the researchers work in companies and $20 \%$ in the Academy, whereas in Brazil it is the opposite (Matias-Pereira, 20II).

In order to conciliate with the Agreement on Trade-Related Aspects of Intellectual Property Rights (TRIPS) proposed by the World Trade Organization, as well as other international intellectual property harmonization initiatives, the Brazilian Government promulgated Law No. 9,279/1996 (Dunagan, 2009; Ryan, 2010). In place up to nowadays, this Law regulates rights and obligations related to industrial property, defines patentability and establishes the procedures for patent application, among other aspects. Furthermore, the Law determines that the National Institute of Industrial Property (INPI), an autarchy of the Brazilian Government funded in 1970, is the agency responsible for coordinating industrial property issues (Brazil, 1996). Indeed, according to INPI's website, the agency was instituted to improve, disseminate and manage the Brazilian system of granting and guaranteeing intellectual property rights to the industry (Brazil, 20I3a).

Nonetheless, Barroso (20II) states that the average lead time from filling to granting (or not granting) a patent in Brazil is of 8.3 years. Although this lead time has been reduced through years, it is still much longer than in developed countries. In the USA and Europe, for example, this lead time is about 3 and 3.7 years, respectively (Mejer and de la Potterie, 20I I). According to Gouveia (2007), the delay in patent examination at the INPI's office is mainly due to an insufficient number of examinees, to the lack of an efficient information system, to corporatism and to the animosity towards the private sector. 
On the other hand, Barroso (20II) alleges that three lines of action are on course to improve INPI's productivity, that is, hiring staff, computerization of patent processing and of review procedures. Barroso (20II) also mentions a bilateral collaboration between Brazil and South Korea to start encouraging small and medium enterprises to increasingly use the industrial property system as a competitive advantage. In addition, INPI is also recognized to have pioneered among developing countries Patent Offices in the implementation of expedited examinations for green technology applications (Lu, 20I3). The goal of INPI is to reduce to two years the examination period of patent applications related to green technologies in the field of alternative energy, transportation, energy conservation, waste management and agriculture (Lu, 20I3).

In Brazil, to be patentable, an invention must meet the requirements of novelty (not already included in the state of the art), inventive activity (it is not evident for a person skilled in the art) and industrial application (it should be possible to produce or use the invention in some sort of industry). It is also necessary to describe the invention clearly and sufficiently, so that one skilled in the art could reproduce it (Brazil, 1996). Unlike other countries, the interpretation of these requirements implicate that new species - except for genetically modified organisms - and substances simply obtained or isolated from their natural environment,

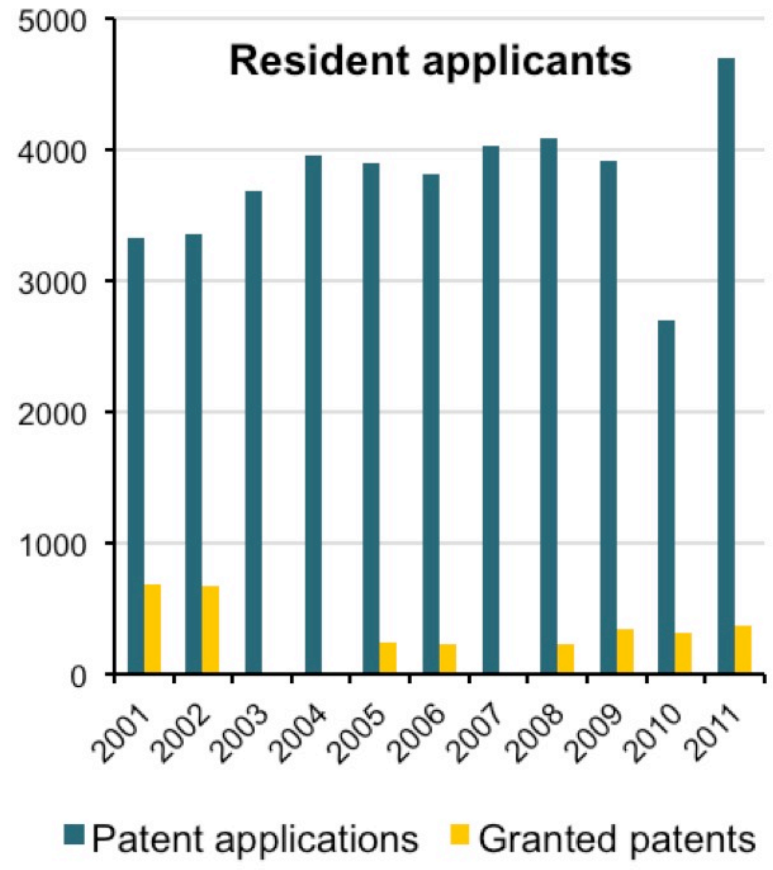

without any inventive activity associated with them - for example, plants and plant extracts - are not patentable in Brazil - though, new extraction procedures and new uses may be patentable (Dunagan, 2009). This peculiarity of the Brazilian industrial property legislation has been object of criticism by Brazilian researchers and inventors, who believe this limitation has driven the country into relevant social and economic losses (Nogueira, Cerqueira and Soares, 2010).

To illustrate industrial property protection in Brazil, Figure I shows general patent information concerning resident and non-resident applicants from all technological fields. In the case of resident applicants, it is noticed that patent applications slightly increased after 2002, remained practically stable from 2004 to 2009, decreased in 2010 (possibly as an effect of global crisis) and peaked in 20 I I. Possibly, this raise in patent applications reflects the incentives of Laws No. 10,973/2004 and No. II, 196/2005 (see section Incentives for innovation in Brazil). In the case of non-resident applicants, it is noticed a general increase trend.

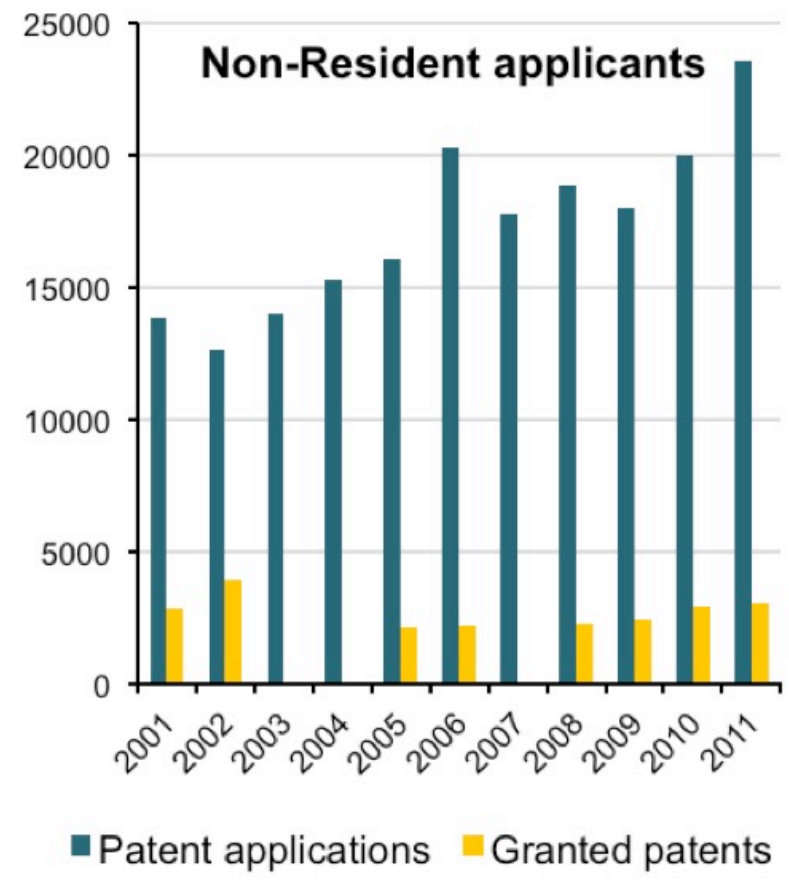

Figure I. Evolution of resident and non-resident patent fillings in all technological fields. Note: data not available for patents granted in 2003, 2004 and 2007. Source: adapted from WIPO (20I3b).

ISSN: 07 I8-2724. (http://www.jotmi.org) 


\section{Biodiversity access in Brazil}

Brazil is the nation with the largest biodiversity of species in the Earth, provided with 6 terrestrial biomes (Amazon, Atlantic Forest, Cerrado, Caatinga, Pantanal and Pampas) and 3 large marine ecosystems (North, East and South Brazilian Coasts) representing at least 103,870 animal species and 43,020 vegetable species (Brazil, 20 I0b). All this biological diversity, along with the traditional knowledge of local communities and indigenous people, are potential sources of innovations for various technological fields.

Nonetheless, history shows that the intervention of the industrialized society in those communities/ecosystems has been exploitative and harmful, both for indigenous people and for natural resources (Dunagan, 2009; Mata et al., 2012). Even some fair trade initiatives - such as the partnership between the cosmetic company The Body Shop and the A'Ukre-Kayapó indigenous villagers for the production of Brazil nut oil, signed in 1991 - in spite of succeeding in raising locals' income and providing access to health facilities, originated other socioeconomic drawbacks, like: a) differences in cash income levels according to gender and age; $b$ ) lack of time to dedicate to subsistence practices and agriculture and c) compromise of social bonds due to lack of time for rituals, socialization and leisure (Ros-Tonen et al., 2008).

With the purpose of discussing the protection of biological diversity and the rights of local communities, in 1992, 156 countries gathered in Rio de Janeiro - Brazil. This event named ECO-92 or Rio-92 originated the Convention on Biological Diversity (CBD), which stated that natural genetic resources would no longer be a patrimony of humanity, but a heritage of the country responsible for the geographical region where those resources are located. In this sense, the access to natural biological resources and to the traditional knowledge of local individuals, for purposes of commercial gains, is subjected to authorization of the respective Government. The CBD also defended the sustainable exploitation of biodiversity, in a way that the use of natural genetic resources are supposed to balance economic development, environmental protection and benefit sharing with local communities and indigenous people (Nogueira, Cerqueira and Soares, 20I0).
In compliance with the CBD, in 200I, the Brazilian Government issued the Provisional Act No. 2,186-16 that regulates the access and commercial exploitation of components of the Brazilian genetic heritage, as well as the traditional knowledge associated to them (Brazil, 200I). In sum, this Act states the following: a) the establishment of the Genetic Heritage Governing Council (CGEN), responsible for managing genetic heritage resources; $b$ ) the obligation to require previous authorization to access components of the Brazilian genetic heritage (native and domesticated), as well as the respective communitarian traditional knowledge, for purposes of scientific research, technological development and bioprospection; and c) the formalization of a Contract for Use of Genetic Heritage and Benefit-Sharing (CURB) with the Government and the indigenous/local community (Brazil, 200I). Additionally, the shipment of samples of components of the Brazilian biodiversity from a Brazilian institution to another Brazilian institution or to foreign countries is subject to approval of CGEN, after clarifying the intended use (Brazil, 200I,Art. 19). The intention of this Provisional Act is to protect Brazilian natural resources against biopiracy and ensure sharing of benefits with indigenous or local communities.

As a consequence of this Provisional Act, in 2006, INPI promulgated a Resolution determining that all patent applicants (from July 0I, 2000 on) must declare whether or not their inventions comprise components of the Brazilian genetic heritage, in the occasion of filling (Brazil, 2006). This resolution was reinforced and updated in 2013 (Brazil, $2013 \mathrm{~b})$. INPI also demands the number of the authorization to access the component of the genetic heritage, according to the Provisional Act.

In spite of the positive intention of the Provisional Act No. 2,I86-16/200I, some Brazilian and foreigner researchers and entrepreneurs have criticized it. From Brazil, for instance, Nogueira, Cerqueira and Soares (2010) affirm that this legislation is far from being effective and Arruda (2009) declares this legislation poses a barrier to research. From abroad,Antonelli and Rodriguez (2009) claim that in spite of the great biodiversity, Brazil has one of the lowest ratios of taxonomists per species, and the current regulation impairs collaboration between Brazilian and foreign researchers. In fact, Magalhães et al. (20l I) observed that the number of Brazilian patents related to herbal extracts is much lower than in the USA or Europe, despite of the greater biodiversity in Brazil. 
As a signatory of the $C B D$, among other targets, Brazil has agreed to encourage an increase in the number of patents sustainably generated from components of local biodiversity (Brazil, 20IOb). Indeed, it is suggested that subjecting traditional knowledge to intellectual property protection, could ultimately promote technological innovations by propagating such knowledge in the industrialized economy (Dunagan, 2009). Even though, Arruda (2009) affirms that while foreign researchers and companies have succeeded in developing and patenting technologies with components of the Brazilian biodiversity, Brazilian counterparts have only succeeded in publishing scientific articles.

In 2010, members of the United Nations adopted the Nagoya Protocol on Access to Genetic Resources and the Fair and Equitable Sharing of Benefits Arising from their Utilization. This Protocol complements the CBD and provides legal transparency to the contracts of access to genetic heritage and the traditional knowledge associated (CURB, in Brazil), for example, by listing some of the acceptable monetary and non-monetary benefits that could be accorded between the parties. Though, Nagoya Protocol must be ratified by 50 State Members before entering into force (United Nations, 20II). In case Nagoya Protocol is ratified, some modifications could be expected in the Provisional Act No. $2,186-16 / 2001$, as well as in the TRIPS Agreement.

In fact, Dunagan (2009) defends that the TRIPS Agreement is biased towards traditional knowledge and does not consider mechanisms to protect indigenous communities' rights, allowing companies to maximize their own profits at the expense of developing countries and their indigenous peoples. On the other hand, the CBD settles on the flaws of TRIPS by preventing biopiracy, so that the latter should eventually be modified to consider such issues. Nonetheless, even with Rio+20 Conference held in 2012, this issue has not yet been properly discussed among the signatories and both agreements coexist.

\section{Skin care}

Brazilians are known worldwide as a people concerned with beauty (Edmonds, 20I0). In fact, Brazil is the third country in the rank of cosmetics consumption in general (more precisely, the second in sun protection and the fourth in other skin cares) and represents a market of more than US\$ 42 billion, with net sales that have raised from US\$ 4.7 to US\$17.5 billion from 1996 to 2012 , according to the Brazilian Association of the Industries of Personal Hygiene, Perfumery and Cosmetics, based on data of the Euromonitor International (ABIHPEC, 20I4). Partially, this positive growth - even in crisis periods - is due to the fact that women historically spend relatively more money on beauty products particularly during economic recessions (at least, since the Great Depression), as a means to enhance their attractiveness (Hill et al., 20I2).

But it is not only about beauty. Firstly, the Brazilian cosmetic industry comprises 2,426 enterprises (with a majority of small and medium-sized companies) and generates almost five million direct and indirect jobs throughout the whole country (ABIHPEC, 20I4). Hence, this sector implies an important socioeconomic aspect. In fact, among the industries supported by the plan Brasil Maior (see section Incentives for innovation in Brazil), Personal Hygiene, Perfumery and Cosmetics is considered a sector intensively affected by import competition and therefore of great priority in terms of strengthening of productive chain (Brazil, 20I4b).

Secondly, skin care is also a matter of well-being. It has been established that cosmetically disfiguring skin disorders (acne, cellulite, folliculitis, psoriasis etc.) can cause considerable discomfort and disability, originating physical, emotional or financial consequences and affecting health status and quality of life (Basra and Shahrukh, 2009). For instance, Mallon et al. (1999) reported that acne patients presented levels of social, psychological and emotional problems similar to those observed in patients with chronic disabling asthma, epilepsy, diabetes or arthritis. Another study related that emotional quality of life of acne patients was as impaired as that of subjects suffering from chronic inflammatory skin diseases such as atopic dermatitis (Hayashi et al., 2005). In fact, the authors noticed that cosmetic anti-acne treatment and camouflage resulted in improved anxiety state (Hayashi et al., 2005). 
Moreover, if used properly and regularly, sunscreens are an effective means to prevent some skin cancers, photoaging and other consequences of sunlight (Duquia et al.,2007; Gilaberte and González, 2010, Green et al., 1999). Particularly in Brazil, a country with high incidence of ultraviolet radiation (Corrêa and Pires, 20I3) and high risk of skin cancer (Brasil, 20l4c), wearing sunscreen is substantially relevant. In fact, statistics from the Brazilian National Cancer Institute (INCA) for 2012 described 134, I70 new cases of non-melanoma skin cancer with I,52I deaths and 6,230 new cases of melanoma skin cancer with I 507 deaths (Brasil, 20 I4c). Thus, the impact of skin cancer in Brazil led the Government to reduce the Tax on Industrialized Products (IPI) from $77 \%$ to $0 \%$ over sunscreen products, in 2006 (Brazil, 2009).

To accomplish those purposes, skin care cosmetics rely on an arsenal of chemical and biochemical technologies, in the form of raw materials. Additionally, raw materials can be synthetized or obtained from natural sources or genetically modified organisms, and finally may be combined to produce cosmetics. Most common forms of skin care cosmetics are emulsions, popularly called creams or lotions, though gels, powders and solutions are also available. In general, cosmetics consist of mixtures of raw materials such as water, oils or fats, polymers, silicones, emulsifiers, thickeners, humectants, preservatives, active ingredients etc. Active ingredients, in their turn, comprise different raw materials with biological activity, for example: vitamins, antioxidants, acids, peptides and botanical extracts, among others (Barel, Paye and Maibach, 2009).

However, due to the trend of green consumerism (Akehurst, Afonso and Gonçalves, 20I2), cosmetic products containing ingredients from natural, renewable and clean sources have gained consumers' attention. Thus, it has been proposed the use of the Brazilian biodiversity for the development of new cosmetic technologies.Arruda (2009), for example, discusses the potential of the Amazon forest for the development of innovations related to skin care raw materials. Garcia, Domingues and Rodrigues (2010), in their turn, relate 85 plant and 12 animal specimens from the Brazilian Atlantic Forest with medical and cosmetic activities. Indeed, some companies have already managed to obtain potential cosmetic ingredients from natural resources of the Brazilian biodiversity (Jorge et al., 2012).
After presenting a background of Brazilian policies towards innovation; industrial property; biodiversity access and skin care businesses, we describe subsequently the methods adopted in this research.

\section{Methods \\ Theoretical design}

Historical data support that high-quality innovations are slightly more likely to be patented than average inventions. Even though some innovations are not patented, patent information has become the standard measure of innovation, due to the absence of economy-wide data on the quantity of innovations (Moser, 2013).

Accordingly, this study is grounded on the assumption that patents are so closely related to the life cycle of technologies, that it is possible to study innovation and technological trends through patent information (Haupt, Kloyer and Lange, 2007). For instance, when a technology is under development, basic scientific and technological issues have to be unraveled and risks must be taken - especially financial ones - in order to accomplish an innovation. Therefore, the number of patent applications is low and increases slowly. Afterwards, as technological and market uncertainties fade, many innovations based on the initial technology are developed and patent applications increase. Eventually, the technology reaches its maturity period and the number of patents at some point declines, though some incremental innovations may remain constant (Gao et al., 20I3; Haupt, Kloyer and Lange, 2007).

In this sense, we employed patent analysis to observe the effects of Brazilian policies towards innovation, industrial property and biodiversity access, on patenting practices of resident and non-resident skin care industries. The next sections describe the procedures employed in this research. 


\section{Patent search and screening}

To collect patent information, we used the search tool available on the homepage of the Brazilian National Institute of Industrial Property (INPI). We searched patent applications which contained any of the key words "cosmetic" or "cosmetics" in their abstract (we actually employed the equivalent terms in Portuguese language, that is, cosmético, cosmética, cosméticos and cosméticas), published from January 0I, 2005 on. Data presented in this paper were updated up to September 03, 2013. Most of patent applications filled from 2012 on were yet kept secret, in accordance with patent legislation (Brazil, 1996, Art. 30). This search protocol resulted in a total of 960 patents that were further screened according to the procedure described in the sequence and illustrated in Figure 2.
In the initial stage, an analyst skilled in cosmetic science read the abstracts and checked the International Patent Classification (IPC) codes attributed to each patent. The IPC is an international agreement on how to systematically classify patentable technologies and inventions (Mendes, Amorim-Borher and Lage, 2013). Then, the analyst selected and tabulated the patents in which the invention was applicable to skin care products. Whenever the abstracts or the IPC codes were not clear enough, the analyst would read the claims and/or the invention description to determine if the patent should be included in the sample. In the final stage, another analyst skilled in cosmetic science read the whole patent documents in order to confirm if the inventions were applicable to skin care products, as well as to understand the inventions and classify the patents. If an invention was considered dubious, the two analysts discussed the invention to reach an agreement.

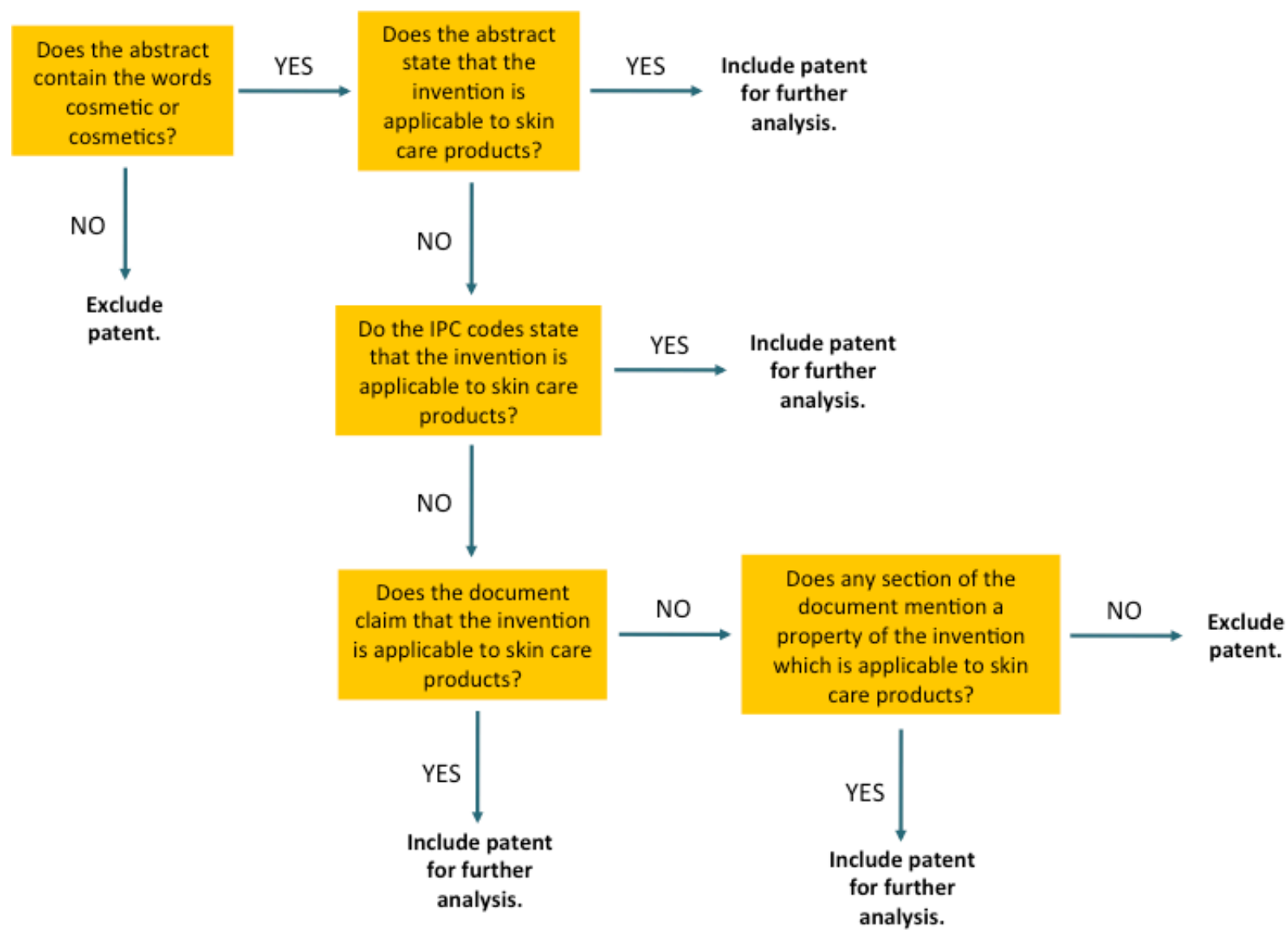

Figure 2. Patent screening procedure.

ISSN: 07 I8-2724. (http://www.jotmi.org) 
This screening procedure resulted in a total of $48 \mathrm{I}$ patents ( $50.1 \%$ of the initial number). Patents related only to non-skin care products (such as hair care, hair removal, deodorants, antiperspirants, make-up and new manufacturing processes etc.) were excluded.

\section{Patent analysis}

We collected information such as applicants' identity, applicants' origin, partnership among applicants and patent application status (application under examination or shelved application).We used this data to present general descriptive information regarding our sample of patent applications.

We also checked if the application was related to Brazilian natural resources. To determine if the invention implicates components of the Brazilian genetic heritage, we verified the geographical origin of the species cited in the applications. In the case of plants and microorganisms, we checked their correspondence with the List of Species of the Brazilian Flora. In the case of animals, we searched the species in the scientific literature.

\section{Sample validity}

Some authors, like Madeira, Borschiver and Pereira-Jr. (20I3), recommend performing the key words search along with a technological codes search, that is, the codes of the International Patent Classification (IPC) system (WIPO, 20I3a). However, we have already reported a few drawbacks of the IPC codes in patent search procedures - such as the insufficiency of codes to describe the whole invention (Souza, Pinheiro and Takahashi, 20I2a), and therefore, we decided to employ them only as a tool for sample validity. Thus, we identified the ten most frequent IPC codes in our sample and we verified all patent applications characterized by such codes (not only skin care-related applications). Consequently, this procedure contemplated patent applications that were not included in our sample, according to the method described in section Patent search and screening. By that means, we expected to confirm if the evolution of patent applications characterized by those ten codes would be similar to our general results.

\section{Results and Discussion}

By and large, this paper analyzed the effects of governmental incentives towards innovation in the Brazilian skin care industry. We also considered the effects of both patent and biodiversity policies on companies' patenting practices, which according to the literature are two factors that have compromised innovation development.

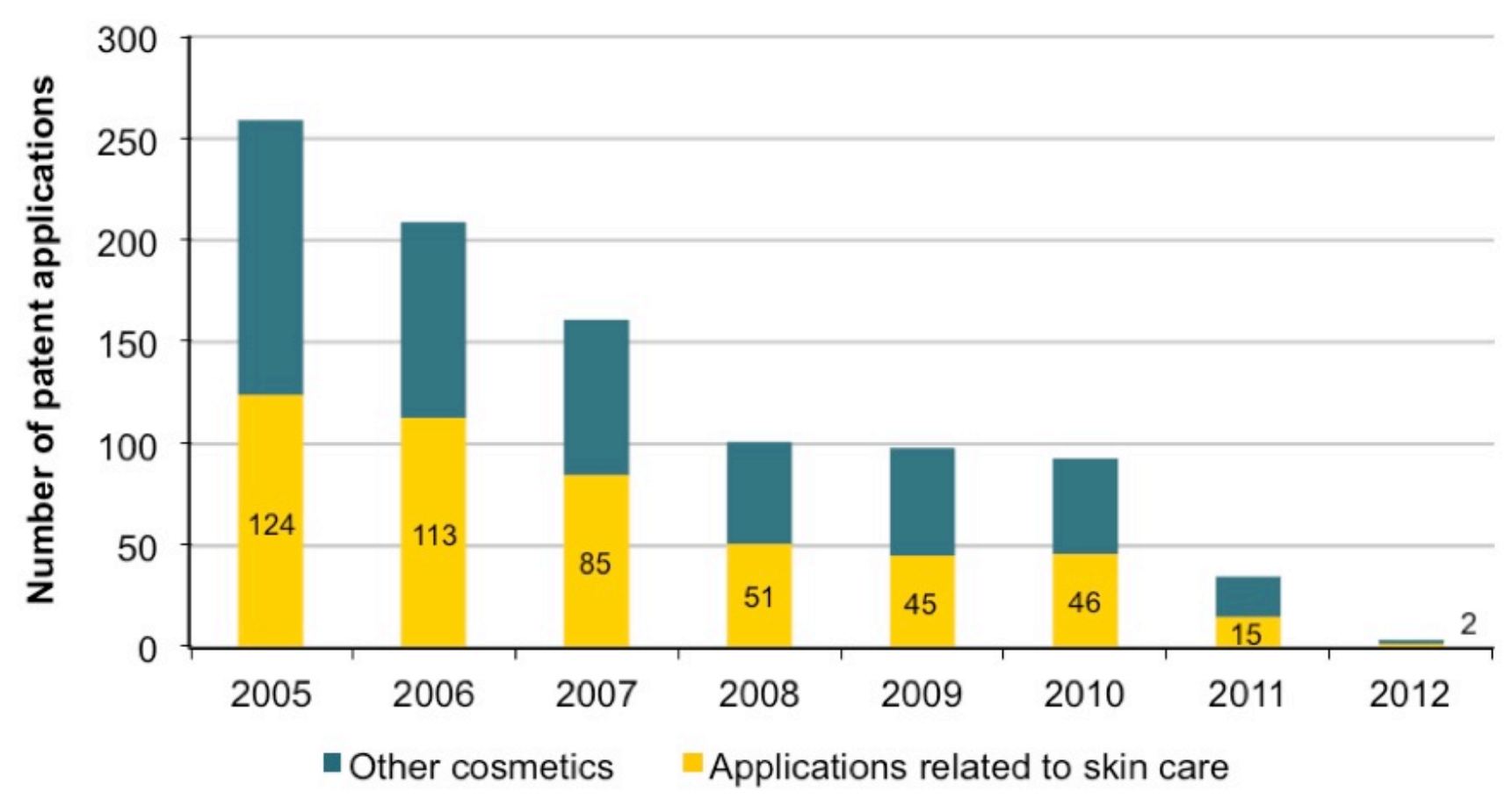

Figure 3. Evolution of cosmetics-related patent applications. $n=960$.

ISSN: 07 I8-2724. (http://www.jotmi.org) 


\section{Evolution of general cosmetic-related patent applications}

In spite of policies and incentives towards innovation in Brazil, we observed that patent applications related to cosmetics in general have decreased since 2005 (see Figure 3 ). For example, the total number of cosmetic-related applications in 2010 barely represented $36 \%$ of the total applications in 2005. Obviously, Brazil is not becoming less competent in cosmetic technology. Instead, this result suggests applicants in this industry have decided not to fill patents in Brazil (or at least to fill a minor number of patents) and, perhaps, protect their inventions by means of industrial secrecy. Further, drop in cosmetic-related patent applications indicates that governmental incentives and policies are not fully effective in this sector. In contrast, in the Brazilian sector of oil and gas, Deorsola et al. (20I3) observed a growth in patent applications particularly from 2004 to 2007 (last year analyzed), when resident applicants practically doubled the number of patent fillings. Mendes, Amorim-Borher and Lage (20I3), in their turn, observed an increase in patent applications in the field of biotechnology only in the years 2007 and 2008, followed by a drop to similar amounts than previous years. Therefore, one may assume that providing incentives to innovation will not impact the different industries equivalently.
It is important to notice that none cosmetic-related patent application was granted (or denied) by the INPI during the period analyzed.Another point to consider is that the effects of the plan Brasil Maior (see section Incentives for innovation in Brazil) cannot be evaluated in this study because most patent applications filled from 2012 on were not available, due to the secrecy period assured by Law No. 9,279//996. However, innovation Laws by themselves could have resulted in some improvements (that is, Law No. 10,973/2004 and No. II,196/2005). In the next sections, we present some considerations with respect to the reasons why cosmetic and skin care patent applications have declined.

\section{Evolution of skin care-related patent applications}

Figure 4 shows the evolution of patent applications in function of the country of the applicant (Brazil and other countries), that is, resident and non-resident applicants. Altogether, the numbers of Brazilian and foreign applications have both declined. Yet we observed a moderate ascension in Brazilian skin care-related applications after 2006, possibly due to the effects of the incentives promoted by Laws No. 10,973/2004 and No. II,196/2005. Nevertheless, the effect of those Laws is clearer only if all technological fields are considered (not exclusively cosmetics), as presented in section Industrial property in Brazil.

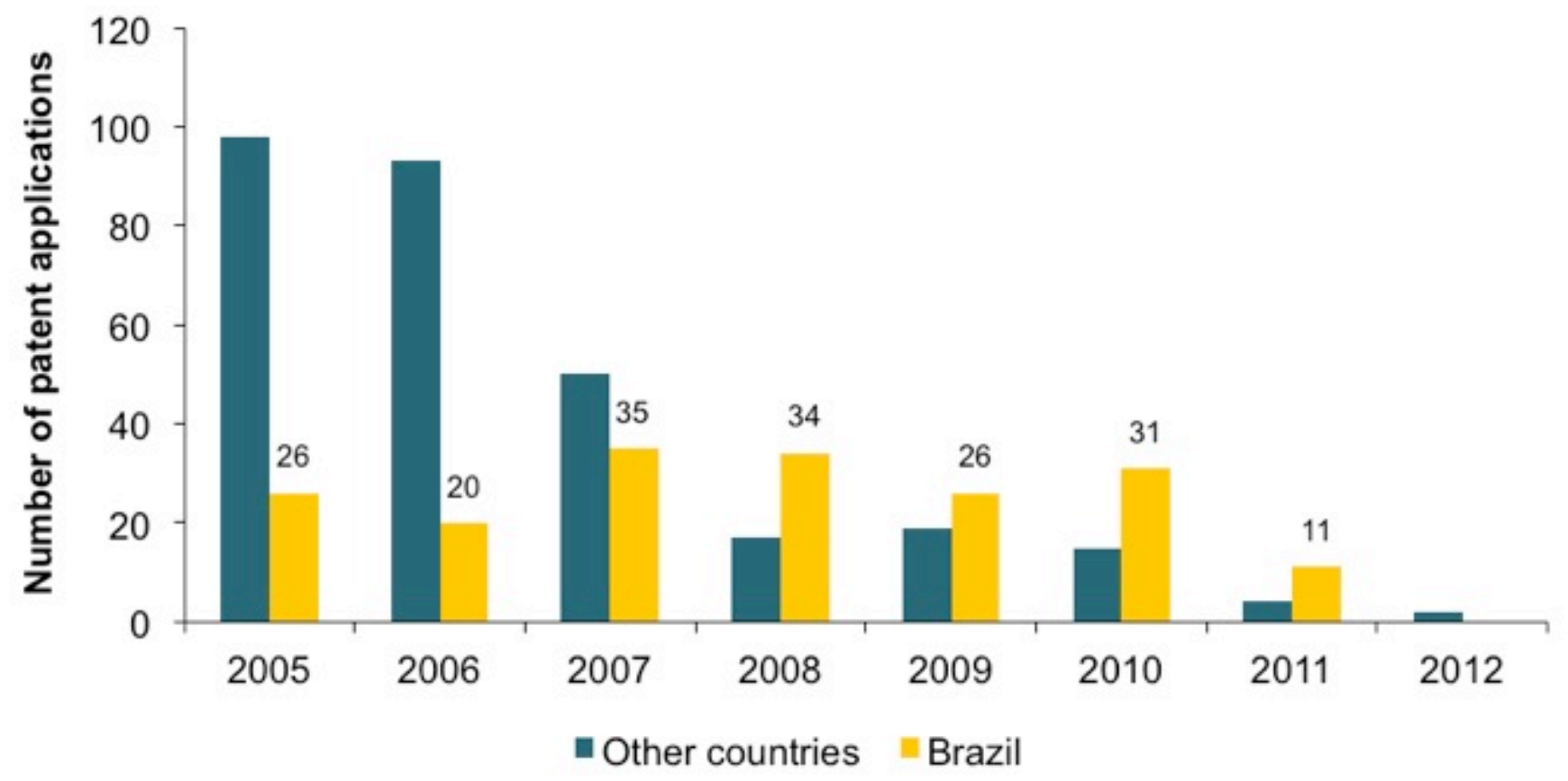

Figure 4. Evolution of skin care-related patent applications per country. $n=48 \mathrm{I}$.

ISSN: 07I 8-2724. (http://www.jotmi.org) 
These results reiterate that, at least in the skin care business, Brazilian companies have not thoroughly benefited from governmental incentives to innovation, otherwise we would have observed greater and increasing numbers of patent applications. It seems that offering tax incentives and funding was not enough to encourage entrepreneurs to invest in research and develop patent-worth technologies. Indeed, developing a new technology demands not only money, but also intellectual capital and a well-equipped infrastructure (Ryan, 2010). Thus, hardly a Brazilian small company would possess by itself all the resources needed to innovate. Actually, according to Ryan (2010), even experienced Brazilian pharmaceutical companies do not possess the whole relevant resources.

Particularly in the case of resident skin care companies, it should be investigated if any national cultural aspect may have motivated the depreciation of patenting practices. For example, Efrat (2014) observed that cultural aspects such as individualism, uncertainty avoidance and power distribution facilitated or impaired innovation in different arrangements throughout 35 countries. Conceivably, Brazil might need to grow a culture of innovation. For instance, the country lacks an effective technological cluster focused in cosmetic technology and based on the models of the Silicon Valley in the USA (Wonglimpiyarat, 2006) or of the Cosmetic Valley in France (Barabel et al., 2009). In general, those clusters are grounded on a cultural willingness to accept risks; dense industrial networks and partnerships; dynamic use of University resources and knowledge interchange; a large pool of scientists, engineers and skilled professionals, as well as the availability of financial resources to support entrepreneurial growth, in which the Government role is limited to foster a favorable business environment (Barabel et al., 2009; Wonglimpiyarat, 2006). Once organized in clusters, skin care companies could benefit from governmental incentives more appropriately, because other issues related to innovation development would be addressed by the cluster itself.

Additionally, the decline of foreign applications may indicate other issues with the Brazilian industrial property system. For example, the lead time of patent examination may have discouraged foreign applicants (and even resident ones). In fact, once a patent proposal is filled, the applicant may claim the privilege over the invention and may legally obtain retroactive rights after the patent is granted. But maintaining a patent application is already an expensive process and not all foreign applicants would like to pursue patent litigations overseas.

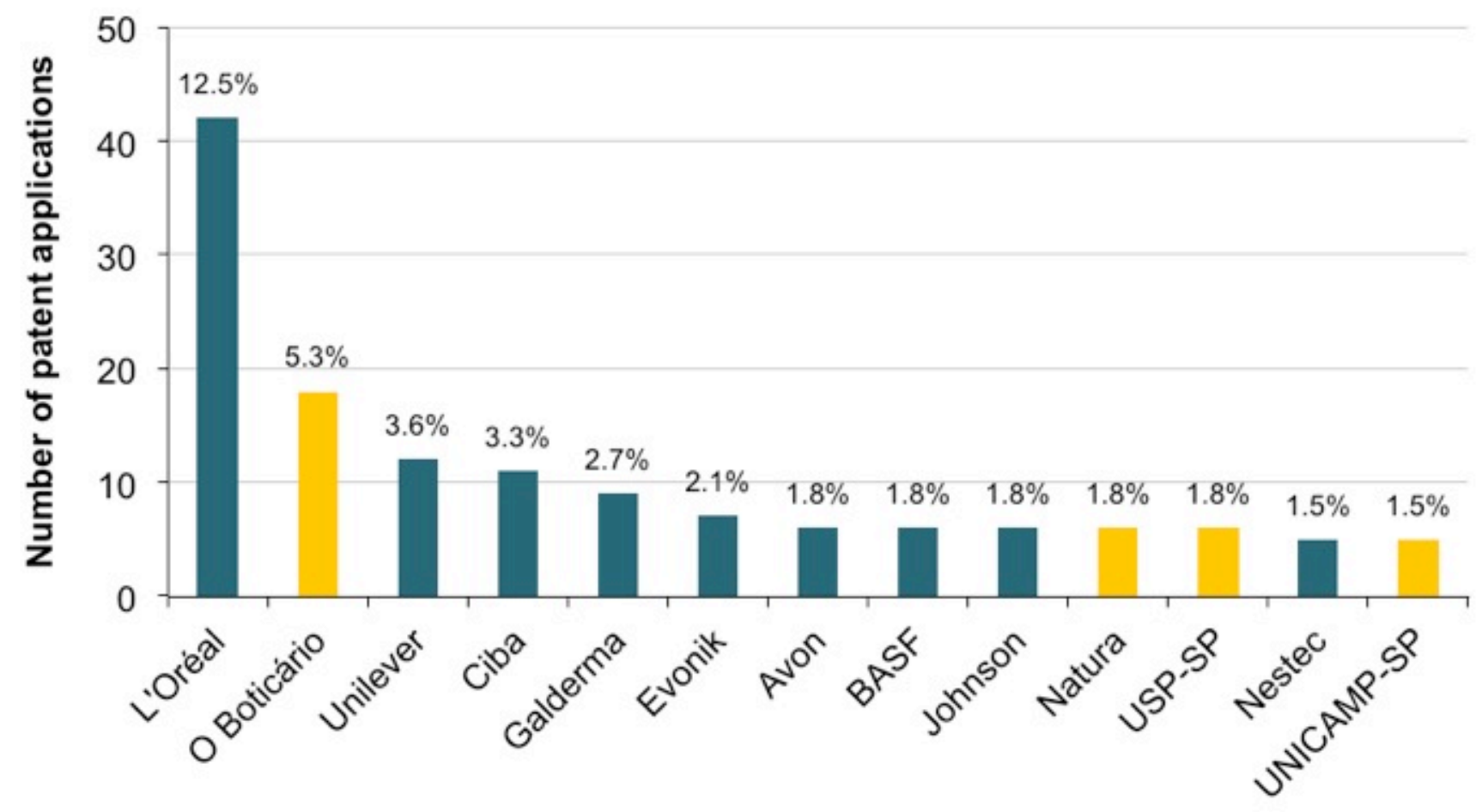

Figure 5. Top applicants of skin-care related patent applications in Brazil.

Notes: Shelved applications and applicants with less than $1.5 \%$ of patent applications were omitted. Brazilian applicants are highlighted. Percentages refer to the total number of patents under examination. $n=337$.

ISSN: 07 I8-2724. (http://www.jotmi.org)

Journal of Technology Management \& Innovation (c) Universidad Alberto Hurtado, Facultad de Economía y Negocios. 


\section{Patent applicants}

Regarding skin care-related patent applications, the majority (38.0\%) was coincidently of Brazilian applicants. In the USA, most of the skin care-related granted patents are from French applicants (Souza, Pinheiro and Takahashi, $2012 b)$. Other countries with relevant participation in this sample were France (20.2\%), Germany (10.6\%), the USA (9.8\%), Switzerland (6.4\%), the Netherlands (4.0\%) and Italy (2.3\%). Among the top applicants (see Figure 5 ) there are two Brazilian companies ( $\mathrm{O}$ Boticário and Natura) and two Brazilian Universities (University of São Paulo - USPSP and University of Campinas - UNICAMP-SP). The top companies are either specialized in final cosmetic products (that is, L'Oréal, O Boticário, Unilever, Galderma, Avon, Johnson \& Johnson and Natura), or are suppliers of cosmetic ingredients (that is, Ciba, Evonik, BASF and Nestec).

Figure 6 presents the evolution of patent applications by type of applicant. We observed that companies filled the majority of the applications (72.8\%), though there were some initiatives from Universities/Research Institutes (9.1\%), independent applicants (that is, natural persons, $8.9 \%$ ) and partnerships among them $(9.1 \%)$. Thus, the drop in cosmeticrelated patent applications is mainly due to the behavior of companies, once the other types of applicants presented a whether cyclic pattern of patent filling.
It is also noticeable that public-private partnerships did not increase, in spite of the encouragement of Law No. 10,973/2004. For example, this Law states that public research institutes may agree to share their infrastructure or their industrial property rights with private companies, as well as license their technology to these companies (Brazil, 2004). In general, resident skin care companies and public Universities/ Research Institutes have not managed to establish fruitful cooperation. In the case of bio-medical industry, Ryan (2010) quotes that one hindrance for public-private partnerships is that researchers and administrators at Brazilian public Universities are not yet acquainted to patent rights, license agreement or royalty rates. In reality, this is quite plausible, if one considers that Law No. 10,973/2004 implemented Nucleuses of Technological Innovation to guide researchers and manage innovation policies in public Institutions, instead of establishing Technology Transfer Offices. Freitas, Marques and Silva (20/3), in their turn, list other barriers to publicprivate research collaboration, for example, bureaucracy in Universities; ownership of project's results and the agility required by the companies.

As suggested earlier, the arrangement of Brazilian skin care companies in clusters (especially for small and medium enterprises) would facilitate innovation. However, the Brazilian Government has granted financial and fiscal incentives before fostering the concretion of effective technological centers. In this sense, the lack of publicprivate partnerships corroborates that simply distributing incentives is not an effective measure if actors involved are not prepared to cooperate in an innovative environment.

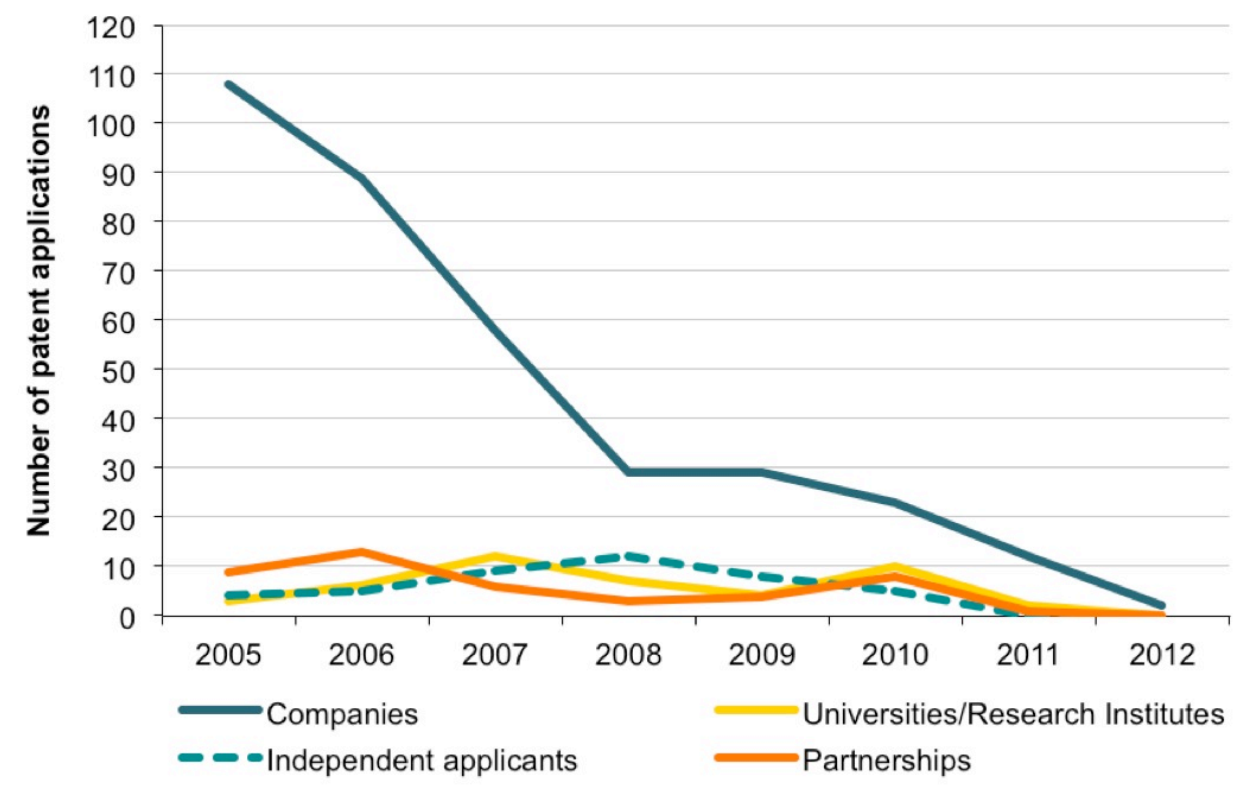

Figure 6. Evolution of skin care-related patent applications per type of applicant. $n=48 \mathrm{I}$.

ISSN: 07 I8-2724. (http://www.jotmi.org)

Journal of Technology Management \& Innovation (c) Universidad Alberto Hurtado, Facultad de Economía y Negocios. 


\section{Biodiversity-related patent applications}

We observed a total of 54 patent applications related to the Brazilian biodiversity. Only one application cited an animal (a domesticated frog) as the source of the technology (an antiacne extract). The remaining 53 applications were related to vegetable components, of which $90.6 \%$ cited native species (instead of domesticated ones). Figure 7 contrasts the evolution of skin care patent applications related or not to components of the Brazilian biodiversity. We observed that the number of biodiversity-related applications plotted a peak in 2007 and then declined.

In fact, only II.2\% of the skin care-related applications made reference to components of the Brazilian genetic heritage (it represented $29.0 \%$ of Brazilian applications). This percentage is dissatisfactory considering the magnitude of the Brazilian biodiversity. Therefore, this result might be related to the impairments introduced by the Provisional Act No. 2,186$16 / 2001$, for example, the need to wait for the authorization of the Brazilian Government before knowing (and researching) if the component presents relevant activities. In addition, some resident large companies have been fined for not meeting the requirements of the referred Provisional Act (Bird, 20l I), what may have intimidated other companies willing to explore local biodiversity.
In relation to the applicants, we observed that most of the biodiversity-related applications were from companies (33.3\%), followed by Universities/Research Institutes (25.9\%) and natural persons (24.1\%). Only one application in the sample was from a foreign applicant, but it referred to a domesticated plant that could have been obtained in other geographical region. This result reinforces the argument that the Provisional Act No. 2,I86-16/200I has also limited the interest of foreign entities in the Brazilian biodiversity, which is plausible once such foreign entity must join a Brazilian public institution to obtain an authorization (Brazil, 200 I,Art. 16, T 6th). Moreover, we also observed some cases in which the applicants presented a clearance certificate attesting they had not accessed components of the Brazilian genetic heritage to develop their invention, even when the cited species are characterized as native and endemic. Possibly, such applicants accessed the components of the biodiversity before July 0I, 2000, when the Provisional Act was not in place; but this information is not available to the public.

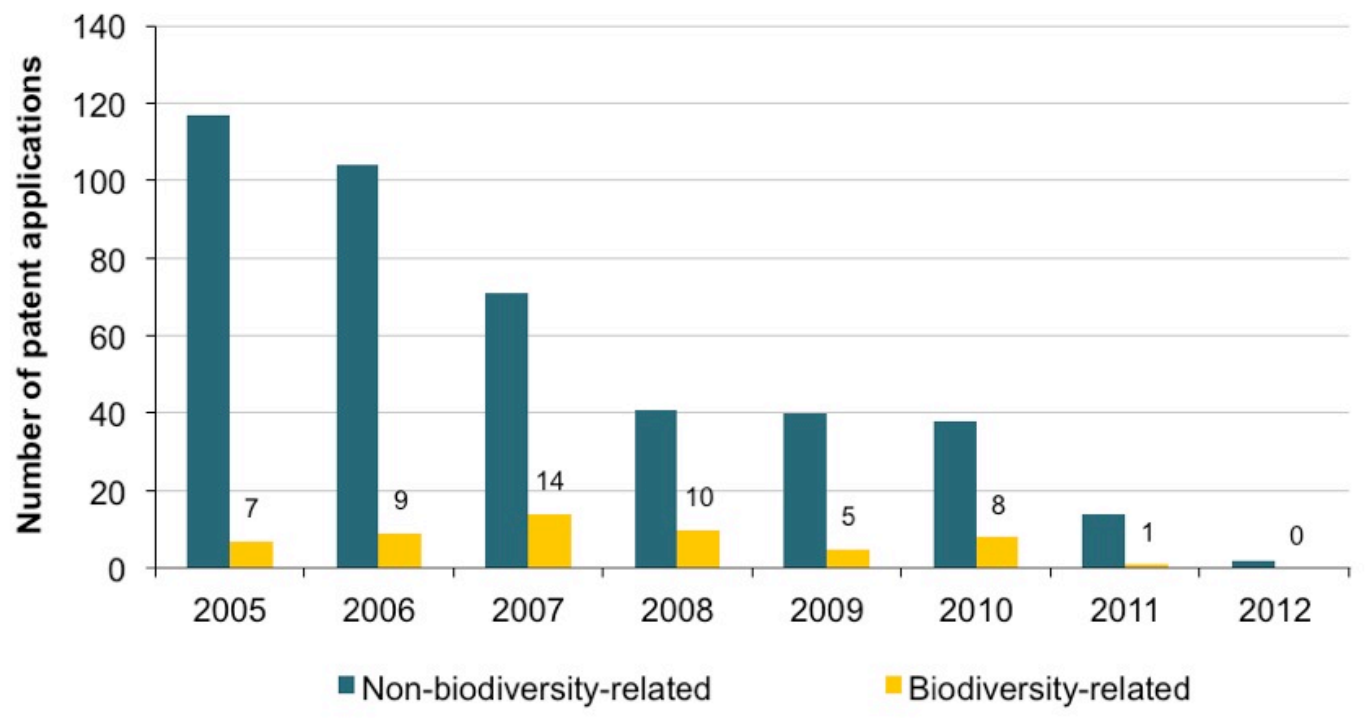

Figure 7. Evolution of biodiversity-related skin care patent applications. $n=481$.

ISSN: 07I 8-2724. (http://www.jotmi.org) 


\section{Status of patent applications}

Most of the skin care-related patent applications in this sample were under the examination period (70.1\%). However, the remaining $29.9 \%$ of those patents were shelved because of one of the following reasons (see Figure 8): I) the applicant did not pay INPI's annuity; 2) the applicant did not requested the examination in proper time; 3 ) the applicant did not submit all the required documents or 4) the applicant filled a later application during the priority period (only two cases). Among the shelved patent applications, 68.8\% were from companies and $18.8 \%$ were from independent applicants. In the case of non-payment of annuity, we observed that the applicants stopped paying fees 6 years after the filling date, on average. Further, from the 54 patent applications related to components of the Brazilian genetic heritage, 16 (29.6\%) were already shelved.

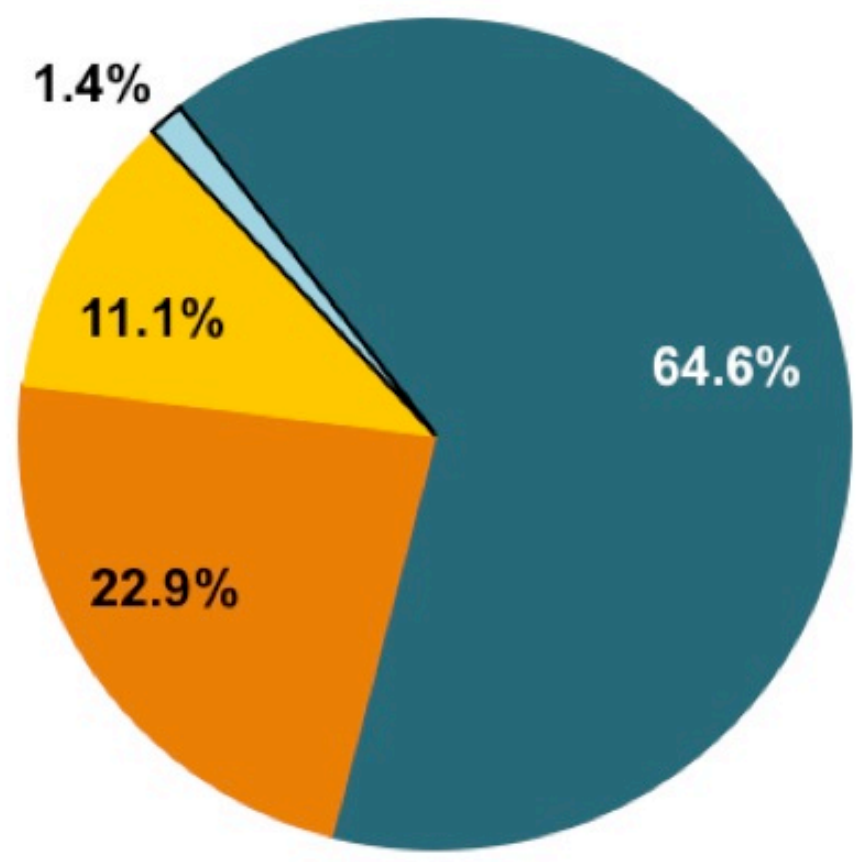

\section{Non-payment of annuity Examination not requested Lack of documents $\quad$ LLater application filled}

Figure 8. Causes of shelving of skin care-related patent applications. $n=144$ 
We could speculate about a few reasons for shelving. First, paying annuities may be difficult for some companies (and mainly for the independent applicants) if no return is realized. It should be considered that from 2005 to 2012 none patent application in this sample was granted or denied by the INPI (approximately 7 years). Second, in the skin care business, some inventions become outdated rapidly and it is possible that the applicants were not interested in them anymore. Indeed, a great deal of patent applications in this sample was related to specific cosmetic formulations, which conceivably may no longer be in the market.Third, applicants may have quitted their applications because they did not find any competitor capable of reproducing their technology in the Brazilian territory. Similarly, these considerations may also be reasons for the drop in the number of new patent applications.

In the case of applications related to components of the Brazilian biodiversity, another motivation for shelving may be supposed.We observed a group of inventors that suggested they filled some patent applications because their goal was to prevent biopiracy, as indicated in the following excerpt of one of those documents:
This patent has the merit of following the trend of employing products derived from natural raw materials, as well as to prevent from practices of biopiracy against our rich biodiversity, further guaranteeing the foundations for sustainable development (Conceição et al., 2007, p. I).

This excerpt discloses the resentment of some Brazilian researchers that face obstacles to scientific exploitation of biodiversity imposed by the Provisional Act No. 2,186$16 / 2001$, whereas foreign researchers and companies may practice biopiracy with exemption. However, the practice of filling a patent application and simply not requesting its examination, in order to prevent others from exploring such technology (by impairing the principle of novelty) may have negative consequences. For example, as well as foreign companies, national companies probably will not be interested in such technology once there is no possibility of patenting.

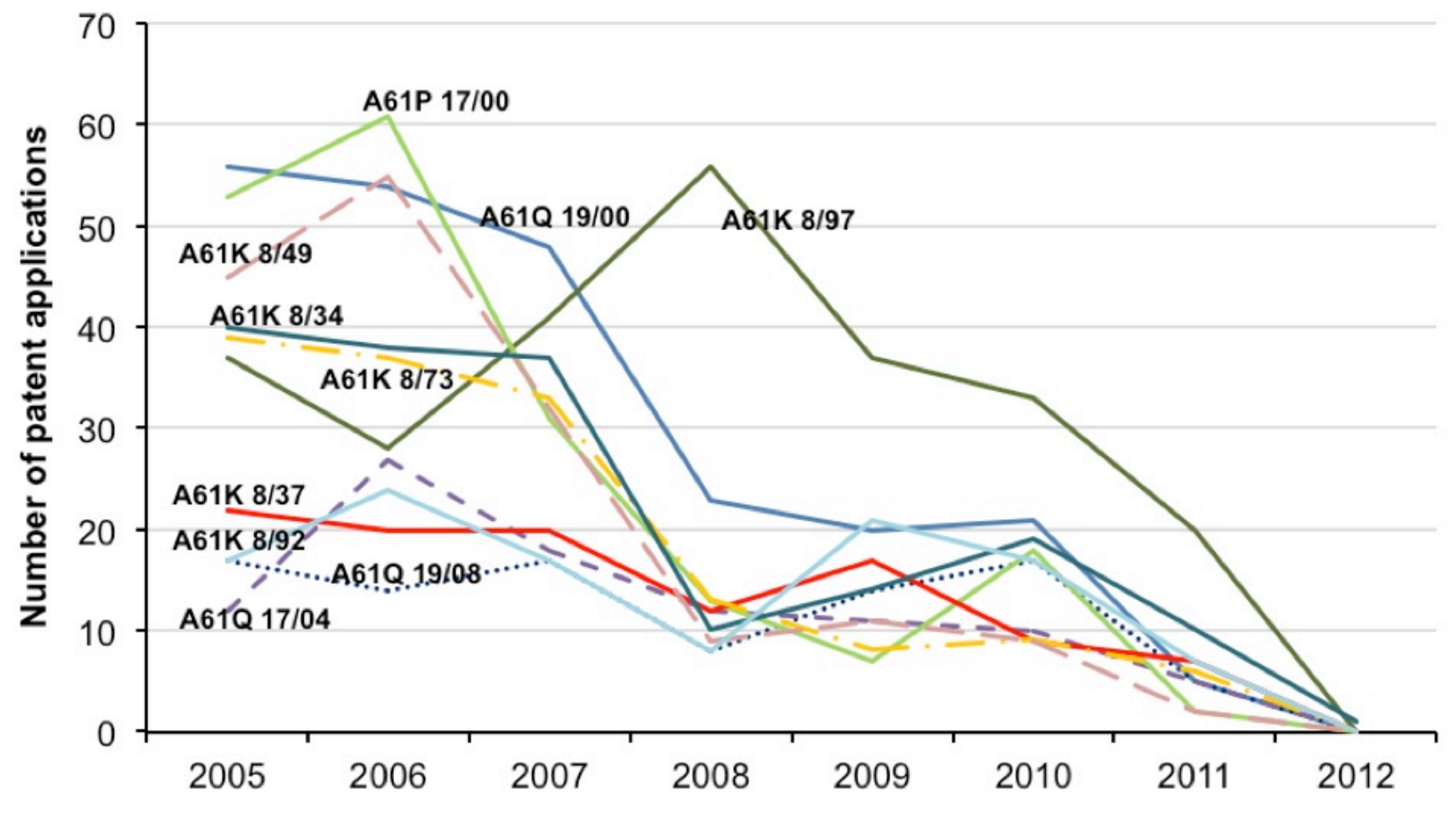

Figure 9. Evolution of patent applications according to International Patent Classification codes.

Note: we considered the ten most frequent IPC codes in our sample. More than one code may have been attributed to the same patent. For further information on IPC codes visit http://www.wipo.int/ipcpub. 


\section{Sample validity}

The ten most frequent IPC codes in our sample were, in descending order, A6IQ 19/00, A6IK 8/97, A6IQ 19/08, A6IQ I7/04, A6IP I7/00, A6IK 8/73, A6IK 8/37, A6IK $8 / 49, A 6 I K ~ 8 / 34$ and $A 6 I K$ 8/92. The evolution of the total amount of applications characterized by those codes was similar to our results (see Figure 9). The number of patent applications containing the ten IPC codes reduced or kept steady since 2007, apart from code A6IK 8/97 (which stands for cosmetic or toilet preparations containing materials of vegetable origin) that started to reduce after 2008. In fact, applications containing the code A6IK $8 / 97$ presented a behavior closer to the applications related to components of the biodiversity, as presented in our sample.Therefore, the drop in patent applications related to skin care cosmetics at INPI's office is further confirmed, reaffirming the validity of our results.

\section{Final Remarks}

This case of the Brazilian skin care industry is exemplary to other developing economies that have implemented or are in the process of renewing their national innovation policies, as well as in the course of adapting to international harmonization agreements (such as the TRIPS, the PCT, the CBD and the Nagoya Protocol).

From this study we can draw the following conclusions:

- Providing incentives to innovation does not necessarily impact different industries in the same manner.

- In the case of Brazilian skin care industry, most of resident companies have not succeeded in thoroughly profiting from governmental innovation incentives.

- Mainly for foreign entities, both patent and biodiversity national policies have negatively affected their interest in Brazil, either because of the delay in patent examination or because of the difficulty to study natural resources.

- $\quad$ Affording financial and fiscal incentives does not necessarily imply in higher rates of innovation. First, other cultural and political issues - such as the ability of stakeholders to cooperate for the sake of innovation - must be previously considered.

- Affording financial and fiscal incentives towards innovation is not an effective measure if other concurrent policies pose a barrier to research and to industrial property protection.

- $\quad$ Finally, the availability of public funding, even as nonrefundable assets, does not guarantee by itself that companies and Universities will cooperate more.
Our conclusions are limited to the implications of patent information and any analysis of our results should consider it. However, patents are a free and public source of technological data, which could not be obtained otherwise due to industrial secrecy. In this sense, while studying companies' innovation performance, patent analysis is more reliable than scientific article bibliometrics, for example. In fact, patents have been widely used as a measure of innovation performance (Deorsola et al., 2013; Gao et al., 2013; Madeira, Borschiver and Pereira-Jr., 2013; Mendes, Amorim-Borher and Lage, 2013; Souza, Pinheiro and Takahashi, 20I2a).

Building upon this paper, we identified some questions for future investigation. For example, what are the specificities of the Brazilian skin care industry that led to the decrease in patent applications, while other sectors are performing up? Why such companies are not thoroughly profiting from governmental incentives? Are there peculiar cultural or political issues to be considered? Therefore, it could be performed a survey with Brazilian skin care industries to identify the types of innovation such companies have accomplished and the hindrances they have faced along the process. Such a study should provide us with a better understanding of the reasons why skin care patent applications have dropped in Brazil. 


\section{Acknowledgements}

The authors gratefully acknowledge PhD Luciana Goulart de Oliveira for her valuable remarks, without attributing responsibility for arguments. Further, the authors would like to thank for the scholarships granted by CNPq (Brazilian Council for Scientific and Technological Development), FAPESP (São Paulo Research Foundation) and CAPES (Brazilian Coordination for the Improvement of Higher Education Personnel).

\section{About the Authors}

Ivan Domicio da Silva Souza, BPharm, MBA, is a PhD Candidate at the Faculty of Pharmaceutical Sciences of Ribeirão Preto, University of São Paulo, Brazil. His thesis is concerned with the future of Brazilian skin care industry and employs a series of foresight methods to support decision and planning in local small and medium enterprises. His work has already received an honorable mention from the Brazilian Association of Cosmetology and he was rewarded with scholarships from Brazilian public agencies (FAPESP, CAPES and CNPq). He was also an intern at UNESCO's Foresight Program.

Tuanny Leite Almeida, is an undergraduate student at the Faculty of Pharmaceutical Sciences of Ribeirão Preto, University of São Paulo, Brazil. Her work aimed to identify technological trends in patent applications related to skin care products and filled in the Brazilian Institute of Industrial Property, INPI. Recently, she studies how small and medium enterprises analyze and generate opportunities for technological innovation. She was rewarded with scholarships from Brazilian public agencies (FAPESP and CNPq) for undergraduate scientists. She was also a project manager at FARMACON JR, an institution attached to the Faculty, which consists of a company managed by undergraduate students.

Vania Passarini Takahashi, BEng, MSc, PhD, is Assistant Professor of Strategy, Innovation and Marketing at the Faculty of Pharmaceutical Sciences of Ribeirão Preto, University of São Paulo, Brazil. She holds a PhD in Management and Industrial Engineering from the University of São Paulo and was Visiting Professor at the Sprott School of Business, Carleton University, Canada. Her research interests include management and strategy of innovation, technological innovations projects and consumer behavior in pharmaceutical and cosmetic industries. She is author of books and papers in management and innovation strategy.

\section{References}

AKEHURST, G., Afonso, C., Gonçalves, H. M. (20I2). Reexamining green purchase behaviour and the green consumer profile: new evidences. Management Decision, 50 (5), 972-988. http://doi.org/ I 0. I 108/0025 I 74 I 2 I I 227726

ANTONELLI, A., Rodriguez, V. (2009). Brazil should facilitate research permits. Conservation Biology, 23 (5), 1068-1069. http://doi.org/I0.1 I I I/j.1523-1739.2009.01300.x

ARRUDA,A.C.(2009).Rede de inovação de dermocosméticos na Amazônia: o uso sustentável de sua biodiversidade com enfoques para as cadeias produtivas da castanha-do-pará e dos óleos de andiróba e copaíba. Parcerias Estratégicas, 14 (29), I 45-I72.

BARABEL, M., Chabault, D., Meier, O., Tixier, J. (2009). La dynamique de territoire et l'evolution d'un pôle de compétitivité: le cas de Cosmetic Valley. Management \& Avenir, 5 (25), I 44-163. http://doi.org// 0.39I7/mav.025.0144

BAREL, A. O., Paye, M., Maibach, H. I. (2009). Handbook of cosmetic science and technology. New York: Informa Healthcare. pp. I-3, I2I-I34.

BARROSO, W. (20II). News from Latin America. World Patent Information, 33 (2), 208-209. http://doi.org//0.1016/j. wpi.20II.0I.006

BASRA, M. K. A. and Shahrukh, M. (2009). Burden of skin diseases. Expert Review of Pharmacoeconomics \& Outcomes Research, 9 (3), 27I-283. http://doi.org/ I0.1586/erp.09.23

BESSANT, J., Tidd, J. (2009). Inovação e empreendedorismo. Porto Alegre, Brazil: Bookman. pp. 19-49.

BIRD, K. (20II). Natura accused of not respecting Brazil's biodiversity laws. Cosmetics Design USA. http://www. cosmeticsdesign.com/Market-Trends/Natura-accusedof-not-respecting-Brazil-s-biodiversity-laws [Accessed September 2, 20I3].

BRAZIL (1996). Law No. 9279, May 14, 1996. Regulates rights and obligations relating to industrial property. http://www. inpi.gov.br/images/stories/Lei9279-ingles.pdf [Accessed December 5, 2012].

BRAZIL (200I). Provisional Act No. 2186-I6, August 23, 200I. Regulates access to genetic heritage and to associated traditional knowledge. http://www.mma.gov.br/estruturas/ sbf_dpg/_arquivos/mp2186i.pdf [Accessed December 5, 20I2]. 
BRAZIL (2004). Law No. 10973, December 2, 2004. Provides incentives for innovation and scientific and technological research. http://www.planalto.gov.br/ccivil_03/_ato20042006/2004/lei//I 0.973.htm [Accessed July 7, 20I3].

BRAZIL (2005). Law No. III96, November 2I, 2005. Regulates taxation. http://www.planalto.gov.br/ccivil_03/_ ato2004-2006/2005/lei/II I I 96.htm [Accessed July 7, 20I3].

BRAZIL (2006). Brazilian National Institute of Industrial Property. Resolution $n^{\circ}$ 134, December 13, 2006. Regulates patent application procedure comprising access to components of the national genetic heritage. http://www. wipo.int/edocs/lexdocs/laws/pt/br/br 102pt.pdf [Accessed July 7,2013$]$.

BRAZIL (2009). Brazilian Agency for Industrial Development. Estudo prospectivo:higiene pessoal, perfumaria e cosméticos. http://www.abdi.com.br/Paginas/estudo.aspx [Accessed August 16,20II].

BRAZIL (2010a). Brazilian Institute of Geography and Statistics. Pesquisa de Inovação Tecnológica - 2008. http:// www.ibge.gov.br/home/estatistica/economia/industria/ pintec/2008/default.shtm [Accessed November 07, 20I I].

BRAZIL (20I0b). Ministry of the Environment. Fourth national report to the Convention on Biological Diversity - Brazil. http://www.cbd.int/doc/world/br/br-nr-04-en.pdf [Accessed July 7, 2013].

BRAZIL (2013a). Brazilian National Institute of Industrial Property. Conheça o INPI. http://www.inpi.gov.br/portal/ artigo/conheca_o_inpi [Accessed July 7, 2013].

BRAZIL (2013b). Brazilian National Institute of Industrial Property. Resolution $n^{\circ} 69$, March 18, 2013. Regulates patent application procedure comprising access to components of the national genetic heritage. http://www.inpi.gov. br/images/stories/downloads/pdf/Normas_Auditoria_ Final_15_3_2013_C.pdf. [Accessed July 7, 20I3].

BRAZIL (20I3c). Funding for Studies and Projects. Chamadas públicas vigentes. http://www.finep.gov.br/editais/vigentes. asp. [Accessed September 16, 20I3].

BRAZIL (2014a). Blog - RHAE - Pesquisador na Empresa. http://www.cnpq.br/web/guest/blog. [Accessed January 16, 2014].

BRAZIL (20I4b). Brasil Maior. http://www.brasilmaior.mdic. gov.br. [Accessed January I4, 20I4].
BRAZIL (20I4c). INCA - Tipos de câncer. http://www2. inca.gov.br/wps/wcm/connect/tiposdecancer/site/home. [Accessed January 20, 20I4].

BRAZIL (20I4d). Ministry of Science, Technology and Innovation. Brasil: dispêndio nacional em ciência e tecnologia (C\&T), 2000-20Il. http://www.mct.gov.br/index. $\mathrm{php} /$ content/view/9058/Brasil_Dispendio_nacional_em_ ciencia_e_tecnologia_C_T_sup_I_sup_html. [Accessed January 29,2014$]$.

BRAZILIAN ASSOCIATION OF THE INDUSTRIES OF PERSONAL HYGIENE, PERFUMERY AND COSMETICS - ABIHPEC (2014). Panorama do setor 2012: higiene pessoal, perfumaria e cosméticos. http://www.abihpec.org. $\mathrm{br} /$ category/publicacoes/panorama-do-setor/ [Accessed January 17, 2014].

CONCEIÇÃO, E. C., Gil, E. S., Garrote, C. F. D., Oliveira, A., Santana, J. C., Silva, E. C. (2007). Creme hidratante (emulsão cosmética) contendo óleo de sementes de guariroba (Syagrusoleracea Becc.). Patent BRPI070I2 I5-2 A2.

CORREA, M. P. \& Pires, L. C. M. (20I3). Doses of erythemal ultraviolet radiation observed in Brazil. International Journal of Dermatology, 52 (8), 966-973. http://doi.org//0.1III/ j. I365-4632.20I2.05834.x

DEORSOLA, A. B., Rodrigues, A. D., Polato, C. M. S., Dupim, L. C. O., Amorim, R. M., Bencke, S. G., Winter, E. (20I3). Patent documents as a technology mapping tool in the Brazilian energy sector focused on the oil, gas and coke industries. World Patent Information, 35 (I), 42-5I. http:// doi.org/I0.1016/j.wpi.20I2.10.006

DUNAGAN, M. (2009). Bioprospection versus biopiracy and the United States versus Brazil: attempts at creating an intellectual property system applicable worldwide when differing views are worlds appart - and irreconcilable? Law and Business Review of the Americas, 15 (3), 603-629.

DUQUIA, R. P., Menezes,A. M. B., Reichert, F. F.,Almeida-Jr., H. L. (2007). Prevalence and associated factors with sunscreen use in Southern Brazil: a population-based study. Journal of the American Academy of Dermatology, 57 (I), 73-80. http:// doi.org/I0.1016/j.jaad.2007.03.012

EDMONDS, A. (2010). Pretty Modern: Beauty, Sex, and Plastic Surgery in Brazil. Durham: Duke University Press.

EFRAT, K. (20I4). The direct and indirect impact of culture on innovation. Technovation, 34 (I), 12-20. http://doi. org//0.1016/j.technovation.2013.08.003 
FREITAS, I. M. B., Marques, R. A., Silva, E. M. P. (20/3). University-industry collaboration and innovation in emergent and mature industries in new industrialized countries. Research Policy, 42 (2), 443-453. http://doi.org/10.1016/j. respol.20I2.06.006

GARCIA, D., Domingues, M. V., Rodrigues, E. (20/0). Ethnopharmacological survey among migrants living in the Southeast Atlantic Forest of Diadema, São Paulo, Brazil. Journal of Ethnobiology and Ethnomedicine, 6: 29. http://doi. org/I0.1 I 86/1746-4269-6-29

GAO, L., Porter,A. L.,Wang, J., Fang, S., Zhang, X., Ma,T.,Wang, W., Huang, L. (20I3). Technology life cycle analysis method based on patent documents. Technological Forecasting \& Social Change, 80 (3), 398-407. http://doi.org//0.1016/j. techfore.20I2.10.003

GILABERTE, Y., González, S. (2010). Update on photoprotection. Actas Dermo-Sifiliográficas, I0I (8), 659672. http://doi.org//0.1016/s/578-2190(10)70696-x

GOUVEIA, F. (2007). Inovação e patentes: o tempo de maturação no Brasil. Inovação Uniemp, 3 (3), 24-25.

GREEN, A., Williams, G., Nèale, R., Hart, V., Leslie, D., Parsons, P., Marks, G. C., Gaffney, P., Battistutta, D., Frost, C., Lang, C., Russell, A. (1999). Daily sunscreen application and betacarotene supplementation in prevention of basal-cell and squamous-cell carcinomas of the skin: a randomised controlled trial. The Lancet, 354 (9/80), 723-729. http://doi. org/ $10.1016 / \mathrm{s} 0140-6736(98) 12168-2$

HAUPT, R., Kloyer, M., Lange, M. (2007). Patent indicators for the technology life cycle development. Research Policy, 36 (3), 387-398. http://doi.org/10.1016/j.respol.2006.12.004

HAYASHI, N., Imori, M., Yanagisawa, M., Seto, Y., Nagata, O., Kawashima, M. (2005). Make-up improves the quality of life of acne patients without aggravating acne eruptions during treatments. European Journal of Dermatology, 15 (4), 284287.

HILL, S. E., Rodeheffer, C. D., Griskevicius, V., Durante, K., White, A. E. (20I2). Boosting beauty in an economic decline: mating, spending, and the lipstick effect. Journal of Personality and Social Psychology 103 (2), 275-29I. http:// doi.org//0.1037/a0028657
JORGE,A.T.S.,Arroteia, K. F., Santos, Í.A.,Andres, E., Medina, S. P.H., Ferrari, C. R., Lourenço, C. B., Biaggio, R. M.T.T., Moreira, P. L. (20/2). Schinus terebinthifolius Raddi extract and linoleic acid from Passiflora edulis synergistically decrease melanin synthesis in BI6 cells and reconstituted epidermis. International Journal of Cosmetic Science, 34 (5), 435-440. http://doi.org/ I0.1 I I I/j. I 468-2494.20 I2.00736.x

LU, B. (20|3). Expedited patent examination for green inventions: developing countries' policy choices. Energy Policy, 6I, I529-I538. http://doi.org//0.1016/j.enpol.2013.06.028

MADEIRA, L. S., Borschiver, S., Pereira-Jr., N. (20I3). On the assignment of biopharmaceutical patents. Technological Forecasting \& Social Change, 80 (5), 932-943. http://doi. org/I0.1016/j.techfore.2012.10.016

MAGALHÃES, W. V., Baby, A. R., Velasco, M. V. R., Pereira, D. M. M., Kaneko, T. M. (20II). Patenting in the cosmetic sector: study of the use of herbal extracts. Brazilian Journal of Pharmaceutical Sciences, 47 (4), 693-700. http://doi. org/I0.1590/SI 984-825020II000400005

MALLON, E., Newton, J. N., Klassen, A., Stewart-Brown, S. L., Ryan, T. J., Finlay, A.Y. (1999). The quality of life in acne: a comparison with general medical conditions using generic questionnaires. British Journal of Dermatology, I 40 (4), 672 676. http://doi.org//0.1046/j.1365-2133.1999.02768.x

MATA, N. D. S., Sousa, R. S., Perazzo, F. F., Carvalho, J. C. T. (20/2). The participation of Wajãpi women from the State of Amapá (Brazil) in the traditional use of medicinal plants - a case study. Journal of Ethnobiology and Ethnomedicine, 8: 48. http://doi:10.1 I86/1746-4269-8-48

MATIAS-PEREIRA, J. (201I). A gestão do sistema de proteção à propriedade intelectual no Brasil é consistente? Revista de Administração Pública, 45 (3), 567-590. http://doi. org/I0.1590/s0034-76I220II000300002

MEJER, M., de la Potterie, B. P. (20I I). Patent backlogs at USPTO and EPO: systemic failure vs deliberate delays. World Patent Information, 33 (2), 122-127. http://doi.org/I0.1016/j. wpi.2010.12.004

MENDES, L., Amorim-Borher, B., Lage, C. (20/3). Patent applications on representative sectors of biotechnology in Brazil: an analysis of the last decade. Journal of Technology Management \& Innovation, 8 (4), 91-102. http://doi. org/| 0.4067/S07 I8-272420I3000500009

MOSER, P. (20I3). Patents and innovation: evidence from economic history. Journal of Economic Perspectives, 27 (I), 23-44. http://doi.org/10.1257/jep.27.I.23 
NOGUEIRA, R. C., Cerqueira, H. F., Soares, M. B. (2010). Patenting bioactive molecules from biodiversity: the Brazilian experience. Expert Opinion on Therapeutic Patents, 20 (2), |45-| 57. http://doi.org/| 0.15 |7//354377090355522 I

ROS-TONEN, M. A. F., van Andel, T., Morsello, C., Otsuki, K., Rosendo, S., Scholz, I. (2008). Forest-related partnerships in Brazilian Amazonia: there is more to sustainable forest management than reduced impact logging. Forest Ecology and Management, 256 (7), I482-I497. http://doi.org//0.1016/j. foreco.2008.02.044

RYAN, M. P. (20I0). Patent incentives, technology markets, and public-private bio-medical innovation networks in Brazil. World Development, 38 (8), 1082-1093. http://doi. org/10.1016/j.worlddev.2009.12.013

SOUZA, I. D. S., Pinheiro, B. J., Takahashi, V. P. (20/2a). A patent survey case: how could technological forecasting help cosmetic chemists with product innovation. Journal of Cosmetic Science, 63, 365-383.

SOUZA, I. D. S., Pinheiro, B. J., Takahashi, V. P. (20/2b). Tendências e benchmarking no setor cosmético. Cosmetics \& Toiletries Brasil, 24 (3), 38-46.

UNITED NATIONS - UN (20II). Nagoya protocol - on access to genetic resources and the fair and equitable sharing on benefits arising from their utilization - to the Convention on Biological Diversity. http://www.cbd.int/abs/ [Accessed August 19, 2013].

VARRICHIO, P., Diogenes, D., Jorge, A., Garnica, L. (20I2). Collaborative networks and sustainable business: a case study in the Brazilian system of innovation. Procedia: Social and Behavioral Sciences, 52, 90-99. http://doi.org//0.1016/j. sbspro.2012.09.445

WEISS, N., Jeffrey, P. (20II). Brazil: Brazil announces new incentives to boost competitiveness of national goods. International Tax Review. http://www.internationaltaxreview. com/IssueArticle/2909570/Archive/Brazil-Brazil-announcesnew-incentives-to-boost-competitiveness-of-nationalgoods.html [Accessed January 16, 2014].

WONGLIMPIYARAT, J. (2006). The dynamic economic engine at Silicon Valley and US Government programmes in financing innovations. Technovation, 26 (9), 108I-1089. http://doi.org//0.1016/j.technovation.2005.09.005

WORLD INTELLECTUAL PROPERTY ORGANIZATION - WIPO (20I3a). International Patent Classification. http:// www.wipo.int/classifications/ipc/en/ [Accessed September $16,2013]$.
WORLD INTELLECTUAL PROPERTY ORGANIZATION - WIPO (20I3b). Statistical Country Profiles. http://www. wipo.int/ipstats/en/statistics/country_profile/countries/ br.html [Accessed July 7, 20I3].

WORLD INTELLECTUAL PROPERTY ORGANIZATION WIPO (2013c). The international patent system - monthly statistics report. http://www.wipo.int/ipstats/en/statistics/ pct/ [Accessed September 16, 2013]. 